\title{
Fossilized pigments as stratigraphic indicators of cultural eutrophication in Shagawa Lake, northeastern Minnesota
}

EVILLE GORHAM* Department of Botany, University of Minnesota, St. Paul, Minnesota 55108

JON E. SANGER Department of Botany and Bacteriology, Obio W'esleyan University, Delaware, Ohio 43015

\section{ABSTRACT}

The recent cultural eutrophication of Shagawa Lake is reflected in the content of fossilized pigments in organic matter from a core of profundal sediment. Concentrations of chlorophyll derivatives and carotenoids in the organic matter of recently deposited sediment ( 1 to $10 \mathrm{~cm}$ deep) are three times as high as in the organic matter of sediment from the presettlement period $(34$ to $149 \mathrm{~cm}$ ). Concentrations of the fossilized pigments prior to settlement also indicate that at that time Shagawa Lake was not among the more oligotrophic lakes on noncalcareous glacial drift in northeastern Minnesota. Owing to cultural eutrophication, it now appears to be the most eutrophic of the northeastern lakes and is probably somewhat more eutrophic than the average lake in Minnesota, although the ratio of sedimentary chlorophyll derivatives to sedimentary carotenoids remains characteristic of its original condition.

\section{INTRODUCTION}

A simple, rapid technique for semiquantitative assessment of the degree of natural or cultural eutrophication in lakes should be of considerable value, particularly if it can be applied stratigraphically to indicate the time of onset and the rapidity of the process. Assessment of presently existing eutrophication normally involves numerous measurements of seasonal primary productivity in light and dark bottles at several depths, whereas stratigraphic assessment depends upon interpretation of nutrient concentrations and diatom, cladoceran, chironomid, or other remains in sediment cores. Concentrations of fossilized chlorophyll derivatives and carotenoids in the organic matter of sediments are closely related to trophic status (Gorham, 1960; Gorham and others, 1974), can serve as stratigraphic indices to it (Gorham, 1961; Sanger and Gorham, 1972; Wetzel, 1970), and are easily measured. Therefore, we conjectured that they would be exceptionally well suited for regional studies of trophic status coupled with investigations of the development of eutrophication within individual lakes. We have tested the utility of this approach by analyzing fossilized pigments in the surface sediments of more than $\mathbf{4 0}$ lakes in Minnesota, in conjunction with an examination of the stratigraphy of fossilized pigments in Shagawa Lake. The cultural eutrophication of Shagawa Lake in northeastern Minnesota has been documented by studies of total phosphorus concentrations as well as of diatom, cladoceran, and other remains in sediment cores (Bradbury and Megard, 1972; Bradbury and Waddington, 1973) and by comparison of the lake's phytoplankton productivity with the productivity of nearby lakes in similar environments much less affected by human activities (Megard, 1969).

\footnotetext{
"Present address: Department of Ecology and Behavioral Biology, University of Minnesota, Minneapolis, Minnesota 55455.
}

\section{RECENT HISTORY OF SHAGAWA LAKE}

Shagawa Lake, which lies in an area of dilute and generally unproductive lakes on Precambrian crystalline rocks, has been considerably disturbed by man since the town of Ely was established beside it in the late $1880 \mathrm{~s}$. Since that time the surrounding forests have been logged and mine wastes have been pumped into the lake (until 1967), which in addition has received the sewage effluent from the town's 5,000 to 6,000 residents and tens of thousands of summer tourists. In recent years the lake has produced dense

TABLE 1. CHARACTERISTICS OF SHAGAWA LAKE, NORTHEASTERN MINNESOTA

\section{Physical characteristics}

Drainage area (includes Burntside

Lake, about $20 \%$ of total

drainage area)

Area

Volume

Mean depth

Maximum depth

Thermocline depth, midsummer

Retention time

Surface temperature

Midsummer transparency

by Secchi disc

$\begin{array}{ll} & 238 \mathrm{~km}^{2} \\ & 9.64 \times 10^{6} \mathrm{~m}^{2} \\ & 59.5 \times 10^{6} \mathrm{~m}^{3} \\ & 6.2 \mathrm{~m} \\ & 14.7 \mathrm{~m} \\ & 3 \text { to } 4 \mathrm{~m} \\ & -1 \mathrm{yr} \\ \text { 3 June } & 14^{\circ} \mathrm{C} \\ \text { 6 August } & 25^{\circ} \mathrm{C} \\ \text { 5 September } & 21^{\circ} \mathrm{C}\end{array}$

Chemical characteristics (surface water)

$\mathrm{pH}$

Salinity $\mathrm{CCa}^{2+}$ and

$\mathrm{HCO}_{3}^{-}$predominant)

Total phosphorus, June-October

Chlorophyll $a$, June-October

$1.8 \mathrm{~m}$

7 to 10

$1.62 \mathrm{meq} / 1$

$84 \mu \mathrm{g} / \mathrm{l}$ (range

26 to 150$)$

$46 \mu \mathrm{g} /$ l (range

11 to 146$)$

\section{Productivity}

Daily gross photosynthesis,

June-October

Annual gross photosynthesis (est.)

\section{Phytoplankton}

Dominant in summer

Dominant in early spring

$$
\begin{aligned}
& 1.4{\mathrm{gC} / \mathrm{m}^{2}}^{2} \\
& \text { (range } 0.5 \text { to } 2.7 \text { ) } \\
& 250 \text { to } 300 \mathrm{gClm}^{2}
\end{aligned}
$$

Aphanizomenon

flos-aquae

Stephanodiscus

minutus,

S. bantzschii

Note: Data from Bradbury and Megard (1972), Bradbury and Waddington (1973), Megard and Smith (1974), and unpublished Environmental Protection Agency data. 
Project of the University of Reading, lingland, made available the facilities of the Okstindsjoen Field Station and provided logistical support, and members of the project assisted with the field work. I thank especially W. H. Theakstone for guidance at all stages of the work and for useful comments on the manuscript. A. G. Milnes and R. P. Sharp also suggested many improvements to the manuscript.

\section{REFERENCES CITED}

Allen, C. R., Kamb, W. B., Meier, M. F., and Sharp, R. P., 1960, Structure of the lower Blue Glacier, Washington: Jour. Geology, v. 68, p. $601-625$.

Ambach, W., 1968, The formation of crevasses in relation to the measured strain rates and stresses: Archiv Meteorologie, Geophysik, u. Bioklimatologie, ser. A, v. 17, p. 78-87.

Anderton, P. W., 1970, Deformation of surface ice at a glacier confluence, Kaskawulsh Glacier, in Bushnell, V. C., and Ragle, R. H., eds., Icefield ranges research project scientific results, Vol. 2: New York, American Geog. Soc., and Montreal, Arctic Inst. North America, p. 59-76.

Colbeck, S. C., and Evans, R. J., 1971, Smallscale strain measurements on a glacier surface: Jour. Glaciology, v. 10, p. 237-243.

Dobrowolski, A. B., 1923, Glaciers, structures and movement theories: Warsaw, Mianowski Institute for the Advancement of Science (English translation in Polisil Geophys. Soc. Bull., Suppl. 1, pt. 16, $1939-1948,191$ p.).

Glen, J. W., 1954, The stability of ice-dammed lakes and other water-filled holes in glaciers: Jour. Glaciology, v. 2, p. 316318.

Grove, J. M., 1960a, The bands and layers of Vesl-Skautbreen, in Lewis, W. V., ed., Norwegian cirque glaciers: Royal Geog. Soc. Research Ser. no. 4, p. 11-23.

- $1960 \mathrm{~b}$, A study of Veslgjuv-breen, in Lewis, W. V., ed., Norwegian cirque glaciers: Royal Geog. Soc. Research Ser. no. 4, p. $69-82$.

Gunn, B. M., 1964, Flow rates and secondary structures of Fox and Franz Josef glaciers, New Zealand: Jour. Glaciology, v. 5, p. $173-190$.

Hambrey, M. J., 1974, The structure of Charles Rabots Bre, Okstindan, Nordland, Norway |lh.l). thesist: Manchester, lingland, Manchester Univ, $18,3 \mathrm{p}$.

-1975a, The flow of Charles Rabots Bre, in Parry, R. B., and Worsley, P., eds., Okstindan research project, preliminary report, 1973: Reading, England, Reading Univ., p. 8-18.

$-1975 \mathrm{~b}$, The origin of foliation in glaciers: Evidence from some Norwegian examples: Jour. Glaciology, v. 14, p. 181-185.

1976, Debris, bubble and crystal fabric characteristics of foliated glacier ice, Charles Rabots Bre, Okstindan, Norway: Arctic and Alpine Research, v. 8, p. 49-60.

Hashimoto, S., Shimizu, H., and Nakamura, K., 1966, Glaciological studies on Antler glacier, Alaska: Hokkaido Univ. Fac. Sci. Jour., ser. 4, v. 13, no. 3, p. 237-256.

Higashi, A., 1967, Ice crystal growth in a temperate glacier in Alaska, in Ôra, H., ed., Physics of snow and ice (Vol. 1): Internat. Conf. on Low Temp. Sci., Hokkaido Univ., 1966 , p. $409-430$.

Holdsworth, G., 1965, An examination and analysis of the formation of transverse crevasses, Kaskawulsh glacier, Yukon: Ohio State Univ. Inst. Polar Studies, Rept. 3, $110 \mathrm{p}$.

-1969, Primary transverse crevasses: Jour. Glaciology, v, 8, p. 107-129.

Hooke, R. LeB., 1973, Structure and flow in the margin of the Barnes Ice Cap, Baffin Island, North-West Territories, Canada: Jour. Glaciology, v. 12, p. 423-438.

Kehle, R. O., 1964, Deformation of the Ross Ice Shelf, Antarctica: Geol. Soc. America Bull., v. 75, p. $259-286$.

Loewe, F., 1955, The depth of crevasses: Jour. Glaciology, v. 2, p. 511-512.

McCall, J. G., 1960, The flow characteristics of a cirque glacier and their effect on glacial structure and cirque formation, in Lewis, W. V., ed., Norwegian cirque glaciers: Royal Geog. Research Ser. no. 4, p. 39-62.

Meier, M. F., 1960, Mode of flow of Saskatchewan glacier, Alberta, Canada: U.S. Geol. Survey Prof. Paper 351, 70 p.

Meier, M. F., and others, 1956, Preliminary study of crevasse formation, Blue Ice Valley, Greenland: U.S. Snow, Ice and Permafrost Research Establisment Rept. 38, 80 p.

Nye, J. F, 1952, The mechanics of glacier flow: Jour. Glaciology, v. 2, p. 82-93.

-1955, Comments on Dr. Loewe's letter and notes on crevasses: Jour. Glaciology, v. 2, p. $512-514$.

1957. The distribution of stress and velocity in glaciers and ice sheets: Royal Soc: London Proc., ser. A, v. 239, p. 113-133.

Post, A., and LaChapelle, E. R., 1971, Glacier ice: Seattle, The Mountaineers, and Seattle and London, University of Washington Press, $110 \mathrm{p}$.

Ragan, D. M., 1969, Structures at the base of an ice fall: Jour. Geology, v. 77, p. 647-667.

Rutter, N. W., 1965, Foliation pattern of Gulkana glacier, Alaska Range, Alaska: Jour. Glaciology, v. 5, p. 711-718.

Schuster, R. C., and Rigsby, G. P., 1954, Preliminary report on crevasses: U.S. Snow, Ice and Permafrost Research Establishment Spec. Rept. no. 11,6 p.

Schwarzacher, W., and Untersteiner, N., 1953, Zum Problem der Bänderung des Gletschereises: Sitzb. Oesterreichischen Akad. Wiss., Math.-Naturw. Kl. IIa, v. 162, no. $1-4$, p. $111-145$.

Seligman, S., 1955, Comments on crevasse depths: Jour. Glaciology, v. 2, p. 514.

Sharp, R. P., 1954, Glacier flow: A review: Geol. Soc. America Bull., v. 65 , p. $821-838$.

1958, Malaspina glacier, Alaska: Geol. Soc. America Bull., v. 69, p. 617-646.

Taylor, L. D., 1962, Ice structures, Burroughs glacier, southeast Alaska: Ohio State Univ. Inst. Polar Studies Rept. 3, $110 \mathrm{p}$.

Theakstone, W. H., Stelzner, K. S., and Knudsen, N. T., 1970, Glacier studies in Nordland Norway: Aarhus Univ., Geog. Inst., Skr. Fys. Geografi no. 1, 96 p.

Turner, F. J., and Weiss, L. E., 1963, Structural analysis of metamorphic tectonites: New York, McGraw-Hill Book Co., 545 p.

Untersteiner, N., 1955, Some observations on the banding of glacier ice: Jour. Glaciology, v. 2 , p. $502-506$.

Weertman, J., 1973, Can a water-filled crevasse reach the bottom of a glacier?, in Symposium on the hydrology of glaciers: Union Géodesique et Géophysique Internat, Assoc. Internat. Hydrologie Sci., Pub. 95, p. $139-145$.

Wilson, G., 1960, The tectonics of the Great Ice Chasm, Filchner Ice Shelf, Antarctica: Geol. Assoc. Proc., v. 71, p. 130-138.

Manuscript Received by THe SOCIety May 20,1975

Revised Manuscript Received february 2, 1976

ManUSCRIPT ACCEPTED MARCH 30, 1976

REPORT No. 17, OKSTINDAN RESEARCH Project 
blooms of diatoms (Stephanodiscus minutus and $S$. hantzschii) in early spring and dense blooms of blue-green algae (Aphanizomenon flos-aquae and Anabaena spp.) in summer. The general characteristics of the lake are given in Table 1, and the chronology of human disturbance, as related to the stratigraphic record by Bradbury and Waddington (1973), is presented in Table 2.

\section{METHODS}

A sediment core $1.5 \mathrm{~m}$ long was taken in December 1973 with a piston sampler in deep water close to the site sampled by Bradbury and Waddington (1973). The core was refrigerated prior to analysis. Samples were taken at $2-\mathrm{cm}$ intervals to a depth of $42 \mathrm{~cm}$ and at $10-\mathrm{cm}$ intervals (in $2-\mathrm{cm}$ slices) to $149 \mathrm{~cm}$. Subsamples were dried at about $105^{\circ} \mathrm{C}$, and organic matter was measured by ignition loss at about $550^{\circ} \mathrm{C}$ (None of the core sediment from Shagawa Lake was sufficiently low in organic content for the bound water of day to introduce serious errors by this procedure.). Average weight loss by ignition is about 2.1 times the organic carbon in Minnesota sediment (Dean, 1974; Dean and Gorham, 1976).

Chlorophyll derivatives, epiphasic carotenoids (predominantly $\beta$ carotene), and hypophasic carotenoids (predominantly lutein) were analyzed in another subsample by solvent partition, as described by Gorham and Sanger (1967) and Sanger and Gorham (1972). Concentrations are expressed in arbitrary units: one pigment unit is equivalent to an absorbence (at the appropriate peak wavelength) of 1.0 in a $10-\mathrm{cm}$ cell when that unit is dissolved in $100 \mathrm{ml}$ of the appropriate solvent.

\section{EXPRESSION AND INTERPRETATION OF PIGMENT DATA}

All pigment data are expressed per gram of organic matter, thus reflecting the degree of pigment preservation relative to that of the total organic matrix in which the pigment occurs. Plant pigments are relatively susceptible to oxidative decomposition, but in productive lakes they tend to be well preserved because the sedimentary organic matter in such lakes is predominantly autochthonous, and rapid burial of the aquatic detritus from which it originates ensures early entry into an anoxic environment favorable for pigment preservation (Gorham, 1960; Gorham and Sanger, 1967, 1975). In unproductive lakes a larger proportion of sedimentary organic matter is allochthonous, and this terrestrial detritus is low in pigments (Gorham and Sanger, 1967; Sanger and Gorham, 1973), owing to its long exposure to oxidation at the soil surface. Even aquatic detritus may be subject to considerable oxidation in cieep unproductive lakes with a long and wholly aerobic water column. Unproductive lakes also have a thicker oxidized microzone at the mud surface (Mortimer, 1941, 1942; Gorham, 1958) and often exhibit a slower rate of sediment accumulation (Pennington and others, 1973), thus allowing greater pigment oxidation at the sediment surface. In this connection Bradbury and Waddington (1973) demonstrated a sharply increased sedimentation rate in Shagawa Lake subsequent to cultural eutrophication.

\section{HEMATITE AS AN INDEX OF HUMAN DISTURBANCE}

The striking increase in hematite grains that marks the onset of mining and human settlement in 1889 was determined by $\mathrm{J}$. Platt Bradbury through microscopic examination of successive $2-\mathrm{cm}$ samples for both hematite and pollen grains. In the present core, hematite increases rapidly relative to pollen between 35 and $33 \mathrm{~cm}$ deep, and it declines (with a decrease in mining activity) above $9 \mathrm{~cm}$ (Fig. 1A). In the core examined by Bradbury and Waddington (1973), hematite increased rapidly between 34 and $30 \mathrm{~cm}$, showing good agreement with our core. Hematite decreased above $15 \mathrm{~cm}$, differing in depth markedly from our core.

Where hematite is high, sedimentary organic matter tends to be iow (Fig. 1B), presumably owing to erosional inputs of mineral matter connected with mining and land clearance.

TABLE 2. STRATIGRAPHY AND CHRONOLOGY OF DISTURBANCE, SHAGAWA LAKE

\begin{tabular}{|c|c|c|c|}
\hline $\begin{array}{l}\text { Depth in } \\
\text { sediment } \\
\text { (cm) }\end{array}$ & Stratigraphic change & Disturbance & Date \\
\hline \multirow[t]{2}{*}{0} & & & 1971 \\
\hline & & Mining discontinued & 1967 \\
\hline 4 & Phosphorus peaks; Fragilaria crotonensis rises again & Sewage plant remodelled & 1963 \\
\hline 10 & $\begin{array}{l}\text { Phosphorus levels off after sharp rise, proportion of } \\
\text { Chydorus levels off, Stephanodiscus peaks }\end{array}$ & $\begin{array}{l}\text { Sewage plant completed, } \\
\text { tourism increases }\end{array}$ & 1954 \\
\hline 14 & $\begin{array}{l}\text { Hematite begins to decline; organic matter begins to rise. } \\
\text { Phosphorus levels off after sharp rise }\end{array}$ & $\begin{array}{l}\text { Mining begins to decline. } \\
\text { Phosphate detergents } \\
\text { come into wide use }\end{array}$ & $1948-1951$ \\
\hline 19 & $\begin{array}{l}\text { Diatom influx increases markedly. Fragilaria crotonensis } \\
\text { begins to decline proportionally; Stephanodiscus } \\
\text { becomes predominant }\end{array}$ & & \\
\hline 25 & Fungal influx peaks; Stephanodiscus begins to rise & & \\
\hline 30 & Hematite maximal; Fragilaria crotonensis begins to rise & Peak in mine production & 1902 \\
\hline 33 & $\begin{array}{l}\text { Hematite begins to rise, organic matter begins to fall, } \\
\text { diatom influx begins to rise }\end{array}$ & Extensive mining begins & 1888 \\
\hline 34 & Fungal influx increases. Slight rise in total phosphorus & $\begin{array}{l}\text { Erosion from logging or } \\
\text { mining? }\end{array}$ & \\
\hline \multirow[t]{2}{*}{$30-40$} & Cladoceran influx increases & & \\
\hline & & Fire & 1875 \\
\hline 39 & $\begin{array}{l}\text { Proportion of white pine pollen declines; that of } \\
\text { Ambrosia rises }\end{array}$ & $\begin{array}{l}\text { Land clearance far south of } \\
\text { Shagawa }\end{array}$ & $\sim 1870$ \\
\hline
\end{tabular}

Note: Data from Bradbury and Waddington (1973). 


\section{PIGMENT STRATIGRAPHY AND PALEOLIMNOLOGY}

Stratigraphic profiles of the sedimentary pigments are shown in Figure $1 C$. Concentrations are relatively constant between depths 34 and $149 \mathrm{~cm}$, averaging 7.0 units per gram of worganic matter for chlorophyll derivatives, 3.5 units for epiphasic carotenoids, and 6.1 units for hypophasic carotenoids. Organic matter also exhibits relatively little variation, averaging 25.3 percent dry weight.

Above $34 \mathrm{~cm}$, where hematite rises sharply, there is not a similar rapid rise in the pigment concentration of sedimentary organic matter, despite the increase in diatom influx rates observed by Bradbury and Waddington (1973). They also observed during this early stage of settlement a very marked peak in the influx of fungal hyphae, together with a high rate of pollen influx. These may reflect land clearance, leading to erosional inputs of forest humus. Because such humus is low in pigments (compare Gorham and Sanger, 1967; Sanger and Gorham, 1973), it would tend to counterbalance an increased influx of aquatic detritus richer in pigments. Calculation of absolute rates of pigment influx would be useful in this situation.

Above a depth of $21 \mathrm{~cm}$, the concentrations of pigments begin to rise rapidly, at about the same level where Bradbury and Waddington (1973) recorded a second increase in diatom influx and a replacement of Fragilaria crotonensis by Stephanodiscus minutus. The phase of rapid increase in pigment concentration continues for about $12 \mathrm{~cm}$. Between 21 and $9 \mathrm{~cm}$ deep, chlorophyll derivatives rise from 7.6 to 20.9 units per gram of organic matter, epiphasic carotenoids from 2.4 to 10.6 units, and hypophasic carotenoids from 6.0 to 18.7 units. It is presumably in this phase of marked eutrophication that blooms of blue-green algae become a significant feature of phytoplankton succession.

Pigment concentrations above $10 \mathrm{~cm}$ tend to level off somewhat, and chlorophyll derivatives average 22.0 units per gram of organic matter, epiphasic carotenoids 11.2 units, and hypophasic carotenoids 18.5 units. Total pigments range between 49 and 56 units per gram of organic matter above $10 \mathrm{~cm}$, as compared with 16.0 units at $21 \mathrm{~cm}$ and 16.6 units in the presettlement period between $34-$ and $149-\mathrm{cm}$ depth, and so a relative stabilization of productivity at a new and distinctly higher level may be inferred.

It is noteworthy that the rapid rise in sedimentary pigments $o$ curs before the decline in hematite, which Bradlumry and Waddington (1973) showed is almost concident with a marked rise in sedimentary phosphorus attributed to the introduction of phosphate detergents. Their data also show that the absolute influx of diatom frustules to the sediment increased sharply before this rise in sedimentary phosphorus and that Stephanodiscus had already begun to replace Fragilaria crotonensis. It appears, therefore, that eutrophication largely preceded the addition of detergent phosphorus and must be ascribed chiefly to a prior influx of sewage.

\section{DISCUSSION}

Figure $1 \mathrm{C}$ demonstrates that the eutrophication of Shagawa Lake is reflected by a marked increase in the concentration of fossilized pigments in sedimentary organic matter. Concentrations of all three types of pigment in organic matter above a depth of $10 \mathrm{~cm}$ in the sediment core are three times as great as those observed in the presettlement era, represented by depths berween 34 and 149 $\mathrm{cm}$. One cannot, however, infer from this a strict threefold increase in productivity, because the relationship between productivity and pigment preservation is not so straightforward (compare Gorham and others, 1974; Daley, 1973; Daley and Brown, 1973). Studies of this relationship are currently being pursued in a diverse series of Minnesota lakes and should eventually allow a more quantitative interpretation of the Shagawa core data.

Another point of interest about Figure $1 \mathrm{C}$ is that the pigment levels in Shagawa Lake sediment prior to settlement are not those of an extremely oligotrophic lake. Figure 2 compares both recent $(0$

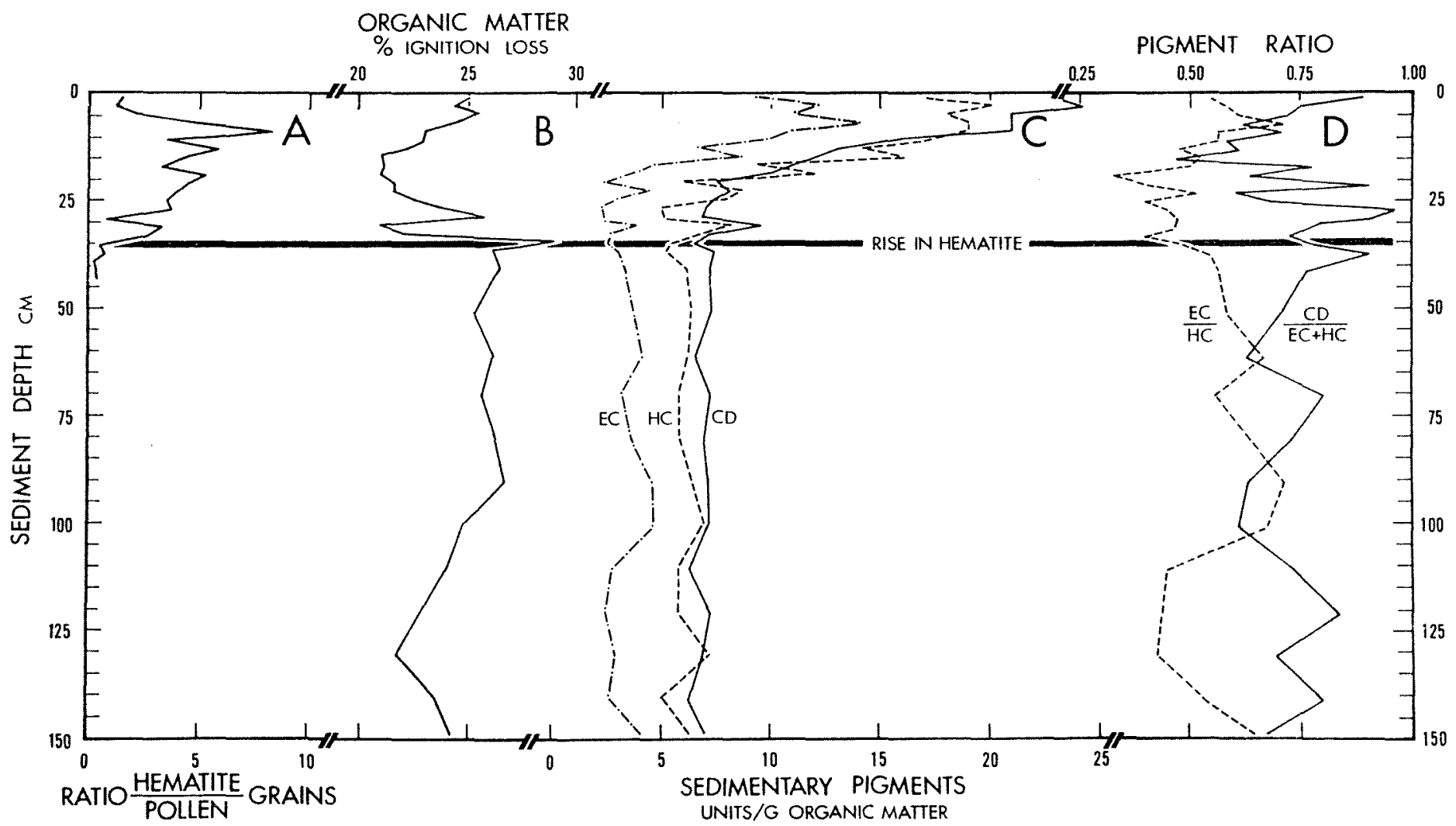

Figure 1. Characteristics of a profundal sediment core from Shagawa Lake in northeastern Minnesota: (A) abundance of hematite grains relative to pollen grains, (B) percentage of organic matter, (C) preservation of fossilized pigments in sedimentary organic matter $(C D=$ chlorophyll derivatives, $E C=$ epiphasic carotenoids, $\boldsymbol{H C}=$ hypophasic carotenoids), (D) ratios of sedimentary pigments. 
to $10 \mathrm{~cm}$ ) and presettlement $(34$ to $149 \mathrm{~cm})$ pigment concentrations in sedimentary organic matter from Shagawa Lake with concentrations in the profundal sedimentary organic matter $(0$ to $10 \mathrm{~cm})$ of 42 holomictic lakes distributed throughout Minnesota and 10 of these holomictic lakes on noncalcareous glacial drift in northeastern Minnesota. The average organic content is much the same in all four groups.

The pigment concentrations in the presettlement sediment of Shagawa Lake are well above the minima for the most oligotrophic lakes shown in Figure 2 and slightly above the means for the northeastern group of oligotrophic to mesotrophic lakes. The presettlement Shagawa Lake means are, however, well below the overall state means (42 lakes), which reflect the eutrophic condition of most Minnesota lakes outside the northeastern region.

The presettlement Shagawa Lake concentrations of chlorophyll derivatives are somewhat greater, and the concentrations of carotenoids somewhat less, than the concentrations in surface sediment of the most productive group of the English Lakes (Gorham and others, 1974). Even the most productive group of the English Lakes exhibits distinctly lower concentrations of sedimentary pigments than the average Minnesota lake.

Pigment concentrations in the organic matter of the most recent $(0$ to $10 \mathrm{~cm})$ Shagawa Lake sediment are distinctly greater than the averages for 42 profundal Minnesota sediments shown in Figure 2, and they reflect the striking influence of eutrophication. This is particularly true for chlorophyll derivatives, which exhibit much

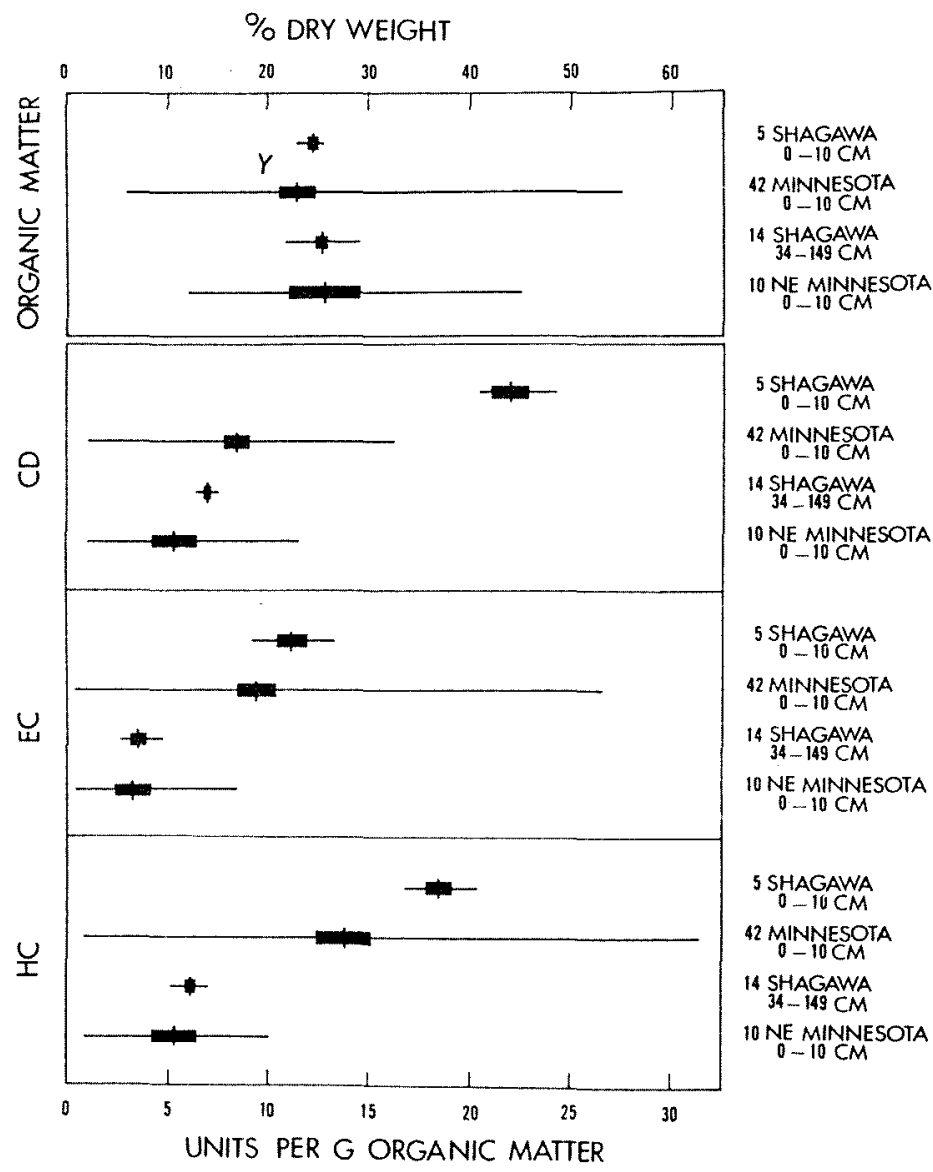

Figure 2. Comparison of organic matter and fossilized pigments in recent $(0$ to $10 \mathrm{~cm})$ and presettlement $(34$ to $149 \mathrm{~cm})$ sediment from Shagawa Lake, profundal surface sediments $(0$ to $10 \mathrm{~cm})$ from 42 holomictic lakes throughout Minnesota, and profundal surface sediments $(0$ to $10 \mathrm{~cm})$ from 10 lakes on noncalcareous glacial drift in northeastern Minnesota $(C D=$ chlorophyll derivatives, $E C=$ epiphasic carotenoids, $H C=$ hypophasic carotenoids). The vertical line marks the mean, the horizontal line the range, and the horizontal band one standard error on each side of the mean.

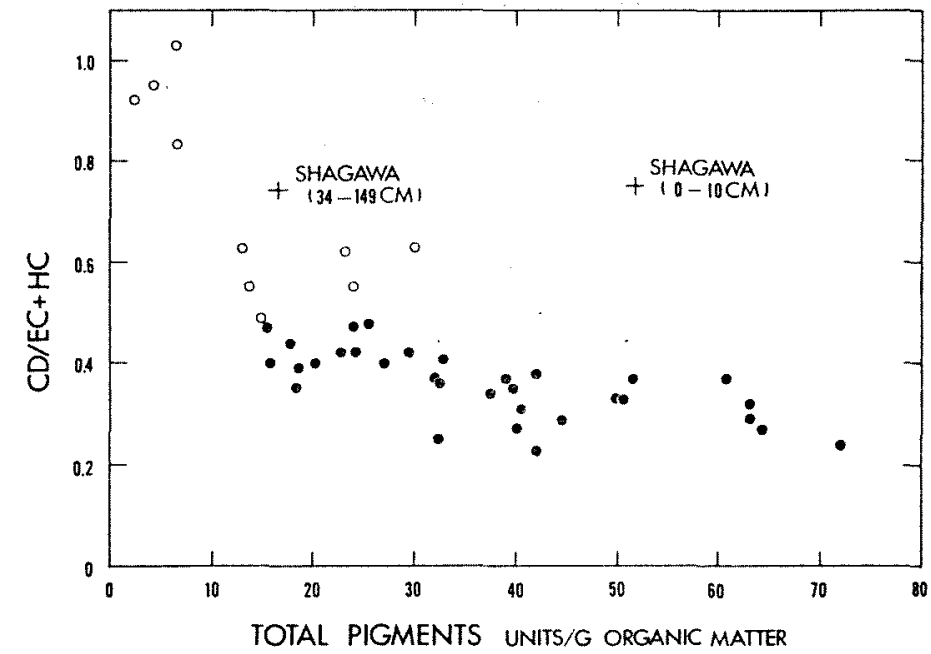

Figure 3. Ratio of chlorophyll derivatives $(C D)$ to total carotenoids (EC $+H C)$ in holomictic Minnesota lakes. Circles indicate northeastern lakes on noncalcareous glacial drift in northeastern Minnesota; dots indicate lakes on calcareous drift elsewhere.

higher concentrations than in any of the 42 holomictic lakes examined in Minnesota. The concentrations of carotenoids, in contrast, lie well within the upper limits for holomictic lakes in Minnesota. The reason for the exceprionally high concentrations of chlorophyll derivatives is unknown.

The above consideration of sedimentary pigments, which may be regarded as biochemical fossils, indicates that they as well as fossilized remains of diatoms and Cladocera can provide an index to eutrophication. In fact, they may serve even better than such remains, because the fossilized pigments reflect the primary productivity of all the plants, including not only the phytoplankton but also to some degree the aquatic macrophytes, which are often neglected in studies of present aquatic productivity. Such macrophytes are abundant in many shallow, eutrophic lakes in Minnesota. In addition, analyses of sedimentary pigments are far less demanding, either of time or of preliminary training, than analyses of fossilized diatoms, Cladocera, and so on. This is not to deny that such analyses are of great value, because they tell a great deal about qualitative as well as quantitative aspects of eutrophication, reflecting as they do changes in species composition and diversity. Moreover, as suggested above, early stages of eutrophication - indicated by greater influx of fossil diatoms - may not be reflected by increased concentrations of sedimentary pigments, if greater inputs of aquatic detritus rich in pigments are counterbalanced by greater erosional inputs of terrestrial humus poor in pigments.

Further information may also be derived from fossilized pigments, although it is seldom easy to interpret. For example, Figure $1 D$ shows pronounced variations in the ratios of chlorophyll derivatives $(C D)$ to total carotenoids and of epiphasic $(E C)$ to hypophasic $(H C)$ carotenoids. These may well reflect changes in the balance among the diatoms, blue-green algae, and aquatic macrophytes that are or have been common in Shagawa Lake and in the ratio of autoch thonous to alloch honous inputs of sedimentary organic matter, but presently we cannot interpret them in the way we have been able to do at Kirchner Marsh (Sanger and Gorham, 1972). Despite the variation in ratios with sediment depth shown in Figure $1 D$, the average ratios for recent times $(0$ to $10 \mathrm{~cm})$ are quite similar to the averages prior to settlement $(34$ to $149 \mathrm{~cm})$. The ratio $C D / E C+H C$ is 0.75 for recent times and 0.74 for presettlement times, and the ratio $E C / H C$ is 0.60 for recent times and 0.57 for the presettlement period. In both cases the ratios are closer to those for the profundal sediments $(0$ to $10 \mathrm{~cm})$ of the oligotrophic to mesotrophic lakes of northeastern Minnesota (average $C D / E C+H C=$ $0.72, E C / H C=0.57$ ) than to the ratios for the sediment of the more eutrophic average Minnesota lake (average $C D I E C+H C=$ 
